\title{
Method of Enterprise Economic Security Evaluation
}

\author{
OLHA SHUMILO ${ }^{1}$, VITALINA BABENKO ${ }^{2}$, LARYSA LIUBOKHYNETS ${ }^{3}$, IRYNA VOLOVELSKA ${ }^{4}$, \\ OLENA AREFIEVA ${ }^{5}$ \\ ${ }^{1}$ Department of Economics, KHARKIV NATIONAL UNIVERSITY OF CIVIL ENGINEERING AND ARCHITECTURE, \\ UKRAINE, Email: olgashumilo0614@gmail.com \\ ${ }^{2}$ International E-commerce and Hotel\&Restaurant Business Department, \\ V. N. KARAZIN KHARKIV NATIONAL UNIVERSITY, UKRAINE Email: vitalinababenko@karazin.ua \\ ${ }^{3}$ Department of Economic Theories, KHMELNYTSKYI NATIONAL UNIVERSITY, UKRAINE \\ Email: lubohinets@ukr.net \\ ${ }^{4}$ UKRAINIAN STATE UNIVERSITY OF RAILWAY TRANSPORT, UKRAINE Email: velya71@mail.ru \\ ${ }^{5}$ Department of Economy of Air Transport, NATIONAL AVIATION UNIVERSITY, UKRAINE \\ Email: elena-2009-19@ukr.net
}

\begin{abstract}
The article examines foreign and domestic experience in organizing financial monitoring systems, systematizes the requirements for its implementation in Ukraine. The basic legal norms, enshrined in the joint directives of the European Parliament and of the Council of the EU, and underlying the national financial monitoring systems of the EU countries and Ukraine have been also analyzed. Taking into account the fact that the risk-based approach is the main basis for the effective implementation of all FATF recommendations, the nature of the risk of $\mathrm{ML}$ / financing of terrorism (FT) and the criteria for their assessment have been investigated. A scheme of improving the process of financial monitoring in a bank has been developed, as well as a number of measures have been proposed to raise the level of adhering to the legislation in the field of anti-money laundering (AML) and counter-terrorist financing (CFT) by the banking sector.
\end{abstract}

Keywords: Economic security; Enterprise; Evaluation; Level; Adaptability.

JEL Classification F30, E44, M31 


\title{
Método de Evaluación de la Seguridad Económica de la Empresa
}

\author{
OLHA SHUMILO ${ }^{1}$, VITALINA BABENKO ${ }^{2}$, LARYSA LIUBOKHYNETS ${ }^{3}$, IRYNA VOLOVELSKA ${ }^{4}$ \\ OLENA AREFIEVA ${ }^{5}$ \\ ${ }^{1}$ Department of Economics, KHARKIV NATIONAL UNIVERSITY OF CIVIL ENGINEERING AND ARCHITECTURE, \\ UKRAINE, Email: olgashumilo0614@gmail.com \\ ${ }^{2}$ International E-commerce and Hotel\&Restaurant Business Department, \\ V. N. KARAZIN KHARKIV NATIONAL UNIVERSITY, UKRAINE Email: vitalinababenko@karazin.ua \\ ${ }^{3}$ Department of Economic Theories, KHMELNYTSKYI NATIONAL UNIVERSITY, UKRAINE \\ Email: lubohinets@ukr.net \\ ${ }^{4}$ UKRAINIAN STATE UNIVERSITY OF RAILWAY TRANSPORT, UKRAINE Email: velya71@mail.ru \\ ${ }^{5}$ Department of Economy of Air Transport, NATIONAL AVIATION UNIVERSITY, UKRAINE \\ Email: elena-2009-19@ukr.net
}

\begin{abstract}
RESUMEN
El artículo examina la experiencia extranjera y nacional en la organización de sistemas de supervisión financiera y sistematiza los requisitos para su aplicación en Ucrania. También se han analizado las normas legales básicas, consagradas en las directivas conjuntas del Parlamento Europeo y del Consejo de la UE, y subyacentes a los sistemas nacionales de supervisión financiera de los países de la UE y de Ucrania. Teniendo en cuenta que el enfoque basado en el riesgo es la base principal para la aplicación efectiva de todas las recomendaciones del $\mathrm{GAFI}$, se ha investigado la naturaleza del riesgo de LD/financiación del terrorismo (FT) y los criterios para su evaluación. Se ha desarrollado un esquema de mejora del proceso de supervisión financiera en un banco, así como se han propuesto una serie de medidas para elevar el nivel de adhesión a la legislación en el ámbito de la lucha contra el blanqueo de capitales (AML) y la financiación del terrorismo (CFT) por parte del sector bancario.
\end{abstract}

Palabras claves: Seguridad económica; Empresa; Evaluación; Nivel; Adaptabilidad.

Clasificación JEL: F30, E44, M31 


\section{Introduction}

The existing scientific methods of evaluating enterprise economic security for the most part duplicate one another and most often are focused on the analysis of financial status, determination of bankruptcy likelihood, enterprise rating and so forth, which only partially provides an evaluation of the economic security level, since many aspects of enterprise economic security are difficult to formalize. The necessity for further search for the most versatile method of evaluating enterprise economic security and development of new tools for its evaluating are stipulated by the existence of such a problem.

\section{Literature review}

In the previous studies there was developed the concept of enterprises economic security management, which is based on the resource and functional approach and provides for the consecutive implementation of certain stages of evaluation within the four blocks: information, methodological support (Cherchyk at.al., 2019; Cherep at. al., 2020; Chorna at. al, .2019; Mahesh at. al., 2020), analytical and resultant (Chorna at.al., 2019; Shumilo, 2017). Within the framework of this approach, a system of economic security evaluation has been formed according to two criteria: economic security level (Utenkova, 2017) and economic security system adaptability (Vasylieva, 2019), which are suggested to be evaluated by means of an integrated index on the basis of a taxonomic approach.

Evaluating enterprise economic security level and economic security system adaptability based on the taxonomic approach involves the formation and calculation of a taxonomic index, which is a synthetic value, formed on the basis of the systems of features indices (Pliuta, 1980; Sablina at.al, 2009).

\section{Data and methodology}

The methodological basis of the study is a set of the following scientific techniques and methods: generalization, synthesis, analysis (during the study of the economic security of the enterprise and analysis of existing methods of assessing its level), construction of an integral index and taxonomic approach (an algorithm for constructing an integral indicator of the level of economic security and adaptability of the system of economic security security), matrix method (adaptability / economic security matrix developed), grouping methods (characteristics of economic her security in accordance with certain criteria).

On the basis of isotonic analysis of the obtained structured information, data subsets, which are homogeneous in the level of features values, are specified in respect to the distinguished components according to the determined criteria: enterprise economic security (financial, market, intellectual and personnel, technological, information, political and legal) and economic security system adaptability (speed, maneuverability, elasticity), that is, isotonic subsets (according to each component) having close structures of features values are obtained (Malyarets at.al., 2019; Utenkova, 2019). The structure of the features values-objects (components) is indicated by the magnitude of the angle between the vectors-objects being considered, and the level of features values-objects is indicated by the length of each vector-object. In the course of constructing a general index on the isomorphic subsets (components of economic security and economic security system adaptability), the form of distribution for each subset is determined, as well as the relationship between them, if any (Babenko at.al., 2019; Perevozova at.al., 2019; Shamraeva, 2018).

In order to construct an integrated index, a reduction of the obtained data is carried out, according to the results of which representatives (indices-representatives) are determined for each component of economic security and enterprise economic security system adaptability (shaikh 2020).

Subsequently, the taxonomic index normalization is conducted, where in the course of performing calculations indices-disincentives are converted to stimulants. Factorial or canonical analysis is applied 
to eliminate the disadvantages or to reduce them, on the results of which the input estimated indices are structured into the subsets by components of economic security and economic security system adaptability, where an aggregate diagnostic index is constructed for each group.

Implementation of the mathematical method of taxonomic index construction (Malyarets and Achkasova, 2012; Pliuta, 1980) for determining the overall levels of enterprise economic security and economic security system adaptability consists of the following stages:

1) conducted standardization of indices. Indices-stimulants, disincentives, nominators are determined among the indices of enterprises economic security level and economic security system adaptability. The number of standard deviations in quotients can be equal to 2 for the symmetric distribution, and 3 for the standard form. To obtain an accurate result, all indices are diagnosed for symmetry.

Standardization: $Z=\left(z_{i j}\right)$

$$
\begin{gathered}
z_{i j}=\frac{x_{i j-\overline{x_{l}}}}{\sigma}, \\
\bar{x}_{\iota}=\frac{1}{n} \sum_{i=1}^{n} x_{i j}, \\
\sigma_{i}=\sqrt{\frac{\sum_{i=1}^{n}\left(x_{i j-\overline{x_{l}}}\right)^{2}}{n}}
\end{gathered}
$$

2) a standard applying descriptive statistics tools is formed

$$
X=\left(x_{i j}\right), i=\overline{1, m}, j=\overline{1, n}
$$

where $\mathrm{i}$ is index, $\mathrm{j}$ - period or object,

3) normalization or standardization of indices of enterprise economic security levels and economic security system adaptability by the components. Two approaches to the standard formation are distinguished:

- a standard in accordance with the "Mini-Max" criterion of the integrated indices level, which are compared locally for each component and their comparison with others is not objective;

- a standard is formed in accordance with the regulatory values of indices, planned, expert, then the evaluation of economic security level is conducted in terms of global comparison and it is possible to compare indices of different groups;

4) the values of the integrated indices of enterprises economic security levels and economic security system adaptability are calculated:

$$
\begin{gathered}
d_{j}=\left(\sum_{i=1}^{m}\left(z_{i j}-z_{i 0}\right)^{2}\right)^{\frac{1}{2}} \bar{d}=\frac{1}{n} \sum_{j=1}^{n} d_{j} \delta=\bar{d} \text { or } \delta=M_{e} ; \\
s_{d}=\left(\frac{1}{n} \sum_{j=1}^{n}\left(d_{j}-\delta\right)^{2}\right)_{;}^{\frac{1}{2}} d=\delta+a s_{d} ; a=3 ; d=\delta+a s_{d} ; \\
I_{j}=\frac{d_{j}}{d} I_{j}^{*}=1-I_{j} .
\end{gathered}
$$

The values of the integrated indices of economic security level and economic security system adaptability of enterprises are in the range from 0 to 1 . The taxonomic index calculated according to this method has the following interpretation: high values of the index indicate a high level of economic security and enterprise economic security adaptability, and low values indicate the low one. 


\section{Results}

According to the suggested method of evaluation where the value of integrated indices of enterprise economic security levels and economic security system adaptability is in the range from 0 to 1 , their instantiation is carried out by the following scale: minimum (0-0.25); normal $(0.25-0.50)$; high (0.5-0.75); maximum (0.75-1.0). The characteristics of economic security levels and enterprise economic security adaptability are presented according to the determined limits (Tables $1 ; 2$ ).

Table 1. Characteristics of enterprise economic security levels

\begin{tabular}{|l|l|l|}
\hline $\begin{array}{l}\text { Economic } \\
\text { security level }\end{array}$ & Scale & Characteristics of enterprise economic security level \\
\hline Minimum & $0-0.25$ & $\begin{array}{l}\text { An enterprise is in a pre-crisis condition, there is a breach of solvency. } \\
\text { Has low financial stability. Inventories of goods at the enterprise } \\
\text { exceed the amount of the enterprise's own working capital and } \\
\text { inventory backed loans. } \\
\text { Profit earning is not guaranteed for an enterprise in this condition, } \\
\text { there is a high risk of loss of solvency. }\end{array}$ \\
\hline Normal & $0.25-0.50$ & $\begin{array}{l}\text { An enterprise is characterized by better performance indices, } \\
\text { average financial stability, an enterprise does not achieve significant } \\
\text { financial results of performance at this level, enterprise solvency is } \\
\text { not stable. }\end{array}$ \\
\hline High & $0.5-0.75$ & $\begin{array}{l}\text { An enterprise is characterized by normal solvency, high financial } \\
\text { stability, has a high margin of competitiveness, shows the ability for } \\
\text { constant development and shows the potential for development. }\end{array}$ \\
\hline Maximum & $0.75-1.0$ & $\begin{array}{l}\text { This level corresponds to the highest results of its performance } \\
\text { achieved by an enterprise and the highest accumulation of its } \\
\text { potential. The financial state of an enterprise is stable and fast- } \\
\text { growing, characterized by a rather high level of solvency in } \\
\text { comparison with other enterprises. }\end{array}$ \\
\hline
\end{tabular}

Table 2. Characteristics of the levels of enterprise economic security system adaptability

\begin{tabular}{|l|l|l|}
\hline $\begin{array}{l}\text { Economic } \\
\text { security level }\end{array}$ & Scale & $\begin{array}{l}\text { Characteristics of the level of enterprise economic security system } \\
\text { adaptability }\end{array}$ \\
\hline Minimum & $0-0.25$ & $\begin{array}{l}\text { It is characterized by the lowest level of enterprise adaptability. An } \\
\text { enterprise can only confront the emerging threats, but not foresee } \\
\text { them, and adapt to changes in the external and internal } \\
\text { environment. }\end{array}$ \\
\hline Normal & $0.25-0.50$ & $\begin{array}{l}\text { At this level, an enterprise is capable of foreseeing threats to } \\
\text { economic security that can emerge, and adapt to both negative } \\
\text { changes in the external and internal environment and positive ones. }\end{array}$ \\
\hline High & $0.5-0.75$ & $\begin{array}{l}\text { A trade enterprise quickly adapts to changes, and at the same time, } \\
\text { restores its financial and economic stability at a high speed. At this } \\
\text { level an enterprise is able to neutralize the threats to economic } \\
\text { security. }\end{array}$ \\
\hline Maximum & $0.75-1.0$ & $\begin{array}{l}\text { Immediate adaptation to changes in the external and internal } \\
\text { environment; threats to enterprise economic security are quickly } \\
\text { eliminated and foreseen at this level; this level is characterized by } \\
\text { the ability to quickly solve problematic situations, which contributes } \\
\text { to the development of an enterprise on the basis of the enterprise } \\
\text { economic state forecasting. }\end{array}$ \\
\hline
\end{tabular}




\section{Discussion}

In order to ensure unambiguous results of evaluating and structuring the state of enterprise economic security we suggest constructing the "economic security/adaptability" matrix, where it is necessary to discriminate quadrants at the intersection of the results of calculating economic security level and adaptability level of economic security system, which allows evaluating the state of enterprise economic security according to substantiated evaluation criteria: enterprise economic security level and economic system adaptability (Fig. 1).

The suggested matrix method makes it possible to conduct quick evaluation of enterprise economic security. Thus, the location of enterprises in the area of the first, second, fifth and sixth quadrants indicates the minimum state of enterprise economic security. If enterprises are in the third, fourth, seventh, eighth and ninth, tenth, thirteenth and fourteenth quadrants according to the results of economic security evaluation, then it indicates the mean state of enterprise economic security. Referring enterprises to the area of the eleventh, twelfth, and fifteenth and sixteenth quadrants, as a result of the economic security evaluation, indicates the state of maximum economic security at an enterprise.

\section{Conclusion}

The suggested scientific and methodological approach to evaluating enterprises economic security, which involves calculation of the integrated index of enterprise economic security level and the integrated index of adaptability level of enterprise economic security, construction of the "economic security/ adaptability" matrix, ensures an unambiguous evaluation of enterprises economic security with the possibility of its grading by levels. The application of this method allows conducting evaluation according to the substantiated criteria and areas of evaluation, which will contribute to making effective managerial decisions as to the stability of its functioning and development. Further research in this area will be related to the selection of the reference data for conducting appropriate calculations.

Figure 1. "Economic security/adaptability" matrix for the enterprise economic security evaluation

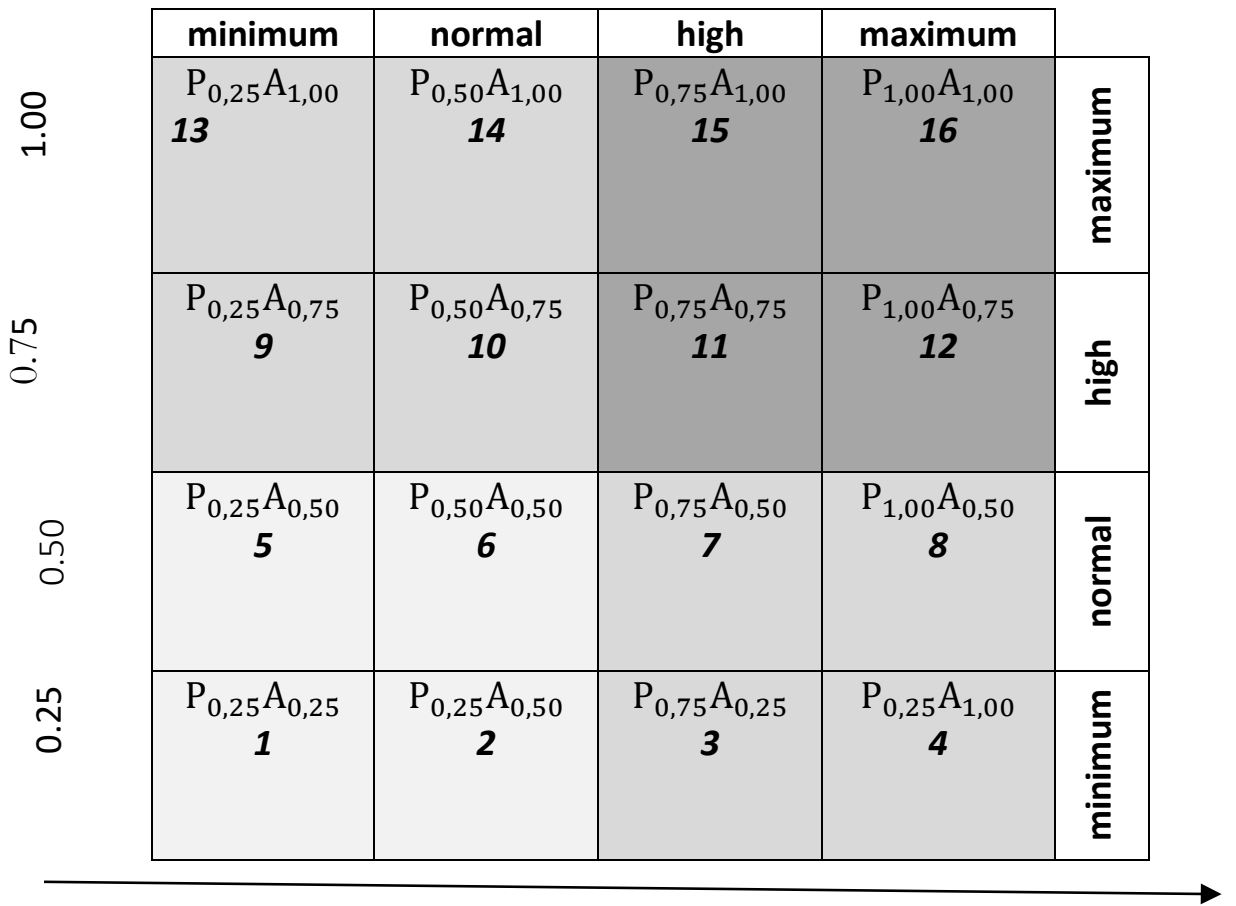

0
0.25
0.50
0.75
1.00

Enterprise economic security level 


\section{References}

1. Babenko, V., Gaponova, E., Nehrey, M., Ryzhikova, N., Zaporozhets, E., 2019, "Life expectancy of population of the country: the role of health services effectiveness", Research in world economy, Vol. 10, No. 4 (Special Issue), pp. 86-91. doi: https://doi.org/10.5430/rwe.v10n4p86

2. Cherchyk, L., Cherchyk A., 2019, "Forest resource security in Ukraine: assessment and provision", Environmental Economics, 10 (1), 105-112. doi:10.21511/ee.10(1).2019.08

3. Cherep, A., Babmindra, D., Khudoliei L., and Kusakova, Yu., 2020, "Assessment of the level of financial and economic security at machine-building enterprises: evidence from Ukraine", Problems and Perspectives in Management, 18(1), 33-47. doi:10.21511/ppm.18(1).2020.04

4. Chorna, M., Filipishyna, L., Nord, G., Tkachenko, S., Velychko, K., 2019, "Analytical support for organizations' economic and environmental safety management", Journal of Security and Sustainability Issues, 8(3), 413-422. https://doi.org/10.9770/jssi.2019.8.3(10).

5. Chorna, M., Shumilo, O., Zabrodska, H., 2019, "The innovative model for the formation of a database used to assess a system of economic security of retail companies", Research in world economy, 10 (4) (Special Issue), 23-30.

6. Davydenko, N.M., 2015, "Modern paradigm of agrarian units' financial security assessment", $\begin{array}{llllll}\text { Ekonomichnyy chasopys XXI. } 5 & (6), \quad \text { pp. 90-93. URL: }\end{array}$ http://soskin.info/userfiles/file/2015/Davydenko.pdf

7. Hryhoruk, P., Khrushch, N., Grygoruk, S., 2019, "Model for Assessment of the Financial Security Level of the Enterprise Based on the Desirability Scale", CEUR Workshop Proceedings, Vol-2422, pp. 169-180. URL: http://ceur-ws.org/Vol-2422/paper14.pdf

8. Kuznetsov, A., Kiian, A., Babenko, V., Smirnov, O., Zhosan, H., and Prokopovych-Tkachenko, D., 2019, "Soft Decoding Method for Turbo-Productive Codes", 3rd IEEE International Conference on Advanced Information and Communication Technologies (AICT), July 2-6, 2019, Lviv, Ukraine.

9. Mahesh, K., Sanjay, G., 2020, "Security perception of e-banking users in India: an analytical hierarchy process", Banks and Bank Systems, 15(1), 11-20. doi: 10.21511/bbs.15(1).2020.02

10.Malyarets, L.M., Achkasova, O.V., 2012, "Zbalansovana systema pokaznykiv yak insteument vyznachennya strategiyi pidpryemstva v umovah kryzy" ["The balanced system of indices as a tool of determining an enterprise strategy under conditions of crisis"]: monograph, Kharkiv, KhNEU, 304 p. [in Ukrainian].

11.Malyarets, L.M., Babenko, V.O., Nazarenko, O.V., Ryzhikova, N.I., 2019, "The Modeling of Multicriteria Assessment Activity in Enterprise Management", International journal of supply chain

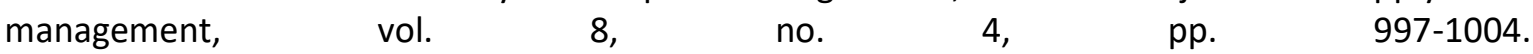
http://www.ojs.excelingtech.co.uk/index.php/IJSCM/article/view/3342

12.Perevozova, I., Daliak, N., Babenko, V., 2019, "Modelling of financial support for the competitiveness of employees in the mining industry", CEUR Workshop Proceedings, vol. 2422, pp. 444-454. URL: http://ceur-ws.org/Vol-2422/paper36.pdf

13.Pliuta, V., 1980, "Sravnitielnyy mnohomernyy analiz $v$ mnohomernyh issliedivaniyah: Metody taksonomii i faktornoho analiza" ["Comparative multidimensional analysis in the economic researches: methods of the taxonomy and the factor analysis"], Moscow: Statistika [in Russian].

14.Sablina, N.V., Telychko, V.A., 2009, "Applying of the taxonomy method for the analysis of the internal resources of the enterprise", Biznes-Inform, 3, 78-82.

15.Shamraeva, V., 2018, "Main theoretical approaches to a concept evolution research international security", The Journal of V.N. Karazin Kharkiv National University Series "International Relations. Economics. Country Studies. Tourism", 8, 88-94. doi: 10.26565/2310-9513-2018-8-09

16. Shaikh Asadullah 2020. The Framework to Analyze the Factors and Aspects of Information Security Program Maturity Grid. International Journal of Advanced Trends in Computer Science and Engineering, Volume 9, No.1.1, PP 311-315, ISSN 2278-3091. Scopus Indexed. 
17.Shumilo, O., 2017, "Kontseptsiya upravlinnya ekonomichnoyu bezpekoyu pidpryemstva rozdribnoyi torgivli" ["The concept of management of retail trade enterprise economic security"], BiznesInform, 3, 219-224 [in Ukrainian].

18.Utenkova, K., 2019, "Economic security as a component of Ukraine's national security", The Journal of V.N. Karazin Kharkiv National University Series "International Relations. Economics. Country Studies. Tourism", 9, 133-144. doi: 10.26565/2310-9513-2019-9-17

19.Vasylieva, N., 2019, "Problems and prospects of food security in Ukraine", Bulgarian Journal of Agricultural Science, 25(4), 668-676. 